\title{
The Effectiveness of Learning with Z-Generation Video on Skeletal System Materials Towards Critical Thinking of Senior High School Students
}

\author{
Riska Septia Wahyuningtyas
}

\author{
Department of Biology Education, Faculty of Teacher Training and Edication, Universitas Kristen Indonesia \\ riska.wahyuningtyas@uki.ac.id
}

\begin{abstract}
This study aimed to determine the effect of the use of learning with Z-generation video on skeletal system material towards critical thinking skills. Z-generation was a generation that was born in 1997 - 2019. This learning was learning process where students are asked to make a video learning material for the skeletal system with contemporary songs, modern song lyrics, and designed according to the style of the younger generation of Z-Generation. This design of research is a quasi-experiment that uses the pretest posttest control group design. The population on this research was all science class $11^{\text {th }}$ in State Senior High School 1 Prambanan consisting of 4 classes. The study sample was taken two classes based on cluster random sampling technique. The class was consisted control class and experiment class. The instruments that used in this study were the observation sheet of learning implementation with Contextual Teaching and Learning approach with Z-generation video, and the test of assessing critical thinking skills. Data from the study were analyzed by ANOVA. The results showed that class scores used learning with Z-generation video was 75.18. While the value of critical thinking of students in the control class is 60.54 . The results of these values indicated students' critical thinking skills that make the Z-generation video higher than the control class. Then it could be concluded that learning with Z-generation video has a positive effect on students' critical thinking skills.
\end{abstract}

Keywords: critical thinking, Z-generation, video

\section{INTRODUCTION}

The new curriculum in Indonesia say that learning Biology must be emphasized on learning direct learning experiences. Biology learning is learning that emphasizes learning activities with life and the object of study is very broad. The object cover all living things. A school teachers in three ways: by what it teaches, by how it teaches, and by the kind of place it is (Joyce et al., 1996). The type of environment will be a consideration in determining how the learning activities are to be carried out. Teachers must use the best learning approach in their learning activities so that learning don't make students boring fin the class.

Learning in Biology must be adapted to 21st Century skills. According to the Partnership for 21st Century Skills (Bell, 2010; Cogan-Drew, 2010; van Laar et al., 2017), 21st Century skills include life and career skills, learning and innovation skills as well as information, media, and technology skills. 21st Century skills focus on critical thinking, problem solving, communication and collaboration skills that are part of High Order Thinking Skills (Johnson, 2009). To get the
21 st century skills, the learning approach that chosen by the teacher must be appropriate to be able to achieve it. Learning approaches that are considered is learning with contextual based approaches. In This approach students made video to apply the matery. Contextual Teaching and Learning (CTL) has been defined here as a way to introduce content using a variety of activelearning techniques designed to help students connect what they already know to what they are expected to learn, and to construct new knowledge from the analysis and synthesis of this learning process. A theoretical basis for CTL has been outlined, with a focus on Connection, Constructivist, and Active Learning theories (Danver, 2016; Hudson and Whisler, 2007)

CTL learning in this research is by making videos based on the lives of $Z$-Generation students. The life of this Z-Generation is meant life with the latest songs, contemporary language, and youth drama today. The process making of this Z-generation video is expected to make students involved in finding material, 
encouraging students to find relationships between the material being studied and real life situations, and encouraging students to apply it in life.

The Contextual Teaching and Learning approach which emphasizing the life patterns of the Zgeneration aims to train students to think critically and skilfully in processing knowledge. It makes the students to find and create something that is beneficial for students themselves and others. Learning that is used in the research is learning with the freedom of students to be creative in making video learning media in the modern Z-generation style.

Critical thinking is an intellectual process that actively and skilfully conceptualizes, applies, analyses, synthesizes, and evaluates information collected or produced from observations, experiences, reflections, reasoning, or communication, to guide beliefs and actions (Buckley et al., 2015; Moon, 2007; Sanders and Moulenbelt, 2011).

Contextual learning by making a life-based video Z-generation uses the steps of Contextual Teaching and Learning. The learning steps contain a contextual learning component. The main components of contextual learning (CTL) include constructivism, inquiry, asking, modelling, learning society, authentic reflection and assessment (Johnson, 2002, 2009).

Biology learning by make videos in accordance with the conditions of modern life Z-generation will eventually to improve students' critical thinking skills in learning to solve real-world problems critically so that what is learned in the environment around contextually can be applied in classroom learning by students. Students will associate contextual matters with theory while learning in class. If the teacher can grow critical attitude, then the process of learning biology i can be an effective, efficient learning activity as well as fun for students and teachers. Students who have high critical thinking skills will usually easily solve a problem.

This research was conducted at Prambanan 1 High School because according to observations during Biology Class. Students had low critical thinking skills. This is proven by very few students asking questions when the teacher shows a case in the worksheet and students are asked to ask questions from the case. Another fact is the students are also less active in expressing opinions when students are asked by teachers to express their knowledge about the objects presented by the teacher in front of the class in implementing sintax of the new curriculum. Students still seem to be silent and do not respond to what the teacher asks learning object. In addition, the results of interviews with showed that students in this high school critical thinking skills are still low, students are less active to ask questions and express opinions in a problem.

From this background the researchers took the title of the thesis "The Effectiveness of Learning with Z-generation Video on Skeletal System Materials toward Critical Thinking of Senior High School Students"

\section{METHOD}

This type of research was Quasi Experiment Research. This research was used was pretest-posttest control group design. This study used two sample classes, namely experimental class and control class. Students in the experimental class were treated by making a video frame system in the current $\mathrm{Z}$ generation style. This Z-generation style is seen in the music style, the scenes in the video drama, the lyrics of the song made, the clothes worn, and the tools used by the Z-generation children.

The independent variable in this research was the application of the Z-Generation Video in the experimental class as $\mathrm{X}$ variable while the control variable in this research was the teacher, the subject matter, and the same time. The dependent variable in this study was critical thinking ability.

The data of this study includes the results of student critical thinking abilities and assessment of Zgeneration Video making. The Instrument in this research was researching the making of Z-generation Video and Question to measure critical thinking abilities. The data obtained from the study were analyzed using SPSS 16 . The data were tested for prerequisite using normality and homogeneity tests, then the data was analyzed by different tests with MANOVA. In the MANOVA test, if the significance $<0.05$ it can be concluded that there is an influence between the approach of learning with critical thinking ability.

\section{RESULT AND DISCUSSION}

This research uses learning approach by making Z-generation learning videos as one form of the realization of the Contextual Teaching and Learning learning model. The Z-generation video was made with the sintax of contextual teaching and learning approach. This Z-generation video was made on skeletal system material. Skeletal systems have mostly memorized and theoretical material. By implementing this video, it is expected that students can better understand the material of the skeletal system without memorization but by watching the videos of other friends and making their own learning videos.

The data obtained in this study came from the results of the pre-test and post-test given to students. 
Students before applying learning by making videos are given a pretest. Then students are given back the posttest questions after the application of learning by making a Z-generation video.

Table 1: Value of Students' Critical Thinking Ability

\begin{tabular}{|c|c|c|}
\hline \multirow{2}{*}{ Subject } & \multicolumn{2}{|c|}{ Critical thinking Ability } \\
\cline { 2 - 3 } & Control & Experiment \\
\hline $\begin{array}{c}\text { Mean } \\
\text { of Pretest }\end{array}$ & 37,92 & 37,09 \\
\hline $\begin{array}{c}\text { Mean } \\
\text { of Postest }\end{array}$ & 60,54 & 75,18 \\
\hline
\end{tabular}

Descriptive analysis was performed using descriptive statistics with SPSS 16 software. Based on the results of the descriptive analysis of the initial critical thinking skills when pretest, the control class got an average of 37.92 and the experimental class got an average of 37.09. This shows that the control and experimental classes have the same initial ability because the average is almost the same where the difference is not too far, which is around 0.83 . The mean difference has also been tested by the average difference test using SPSS which has a significance value of 0.740 . If $\mathrm{p}>0.05$ then $\mathrm{H} 0$ is accepted, which means there is no difference in the value of the pretest of the critical thinking ability of the control class and the experimental class. So that it meets the requirements if both classes are used for experimental research samples because both classes have the same critical thinking ability.

The results of the pretest and posttest control and experimental classes were then tested for normality and homogeneity using normality and homogeneity tests. From the results of homogeneity and normality test results obtained are all normal and homogen in data. Then the posttest value will be further analyzed by SPSS using the MANOVA test. MANAOVA test results are presented in the table 2 .

Table 2: MANOVA Test Results Test between Subjects Effects

\begin{tabular}{|l|l|l|l|}
\hline Source & $\begin{array}{l}\text { Dependent } \\
\text { Variabel }\end{array}$ & $\begin{array}{l}\text { Mean } \\
\text { square }\end{array}$ & Sign \\
\hline $\begin{array}{l}\text { Corrected } \\
\text { Model }\end{array}$ & Critical & 2474.584 & .000 \\
\hline Intercept & Critical & 215875.776 & .000 \\
\hline Approach & Critical & 2474.584 & .000 \\
\hline
\end{tabular}

From Table 2 Test between Subjects Effects above, it can be seen that the probability or significance value between the learning approach and critical thinking skills is 0,000 . Decision making is based if $p>$ $0.05 \mathrm{HO}$ is accepted, whereas if $\mathrm{p}<0.05 \mathrm{HO}$ is rejected.
If you see the significance value of the learning approach with critical thinking skills that is equal to $0,000<0.05$ then the null hypothesis is rejected. The conclusion is that there are differences in the ability to think critically between classes that use a learning approach by making video Z-generation learning and conventional learning. The value of the experimental class has a higher critical thinking ability value compared to the control class. The difference in value has been proven by the results of the MANOVA test which states the difference is very real. It can also be said that learning by making a Z-generation video influences students' critical thinking skills.

The results showed that the critical thinking skills of control and experimental class students were the same when given a pretest before the learning took place. But after learning by giving treatment, the results obtained from the students' critical thinking ability of the experimental class were higher when compared to the control class. This can be seen in the graphic value of critical thinking skills below.

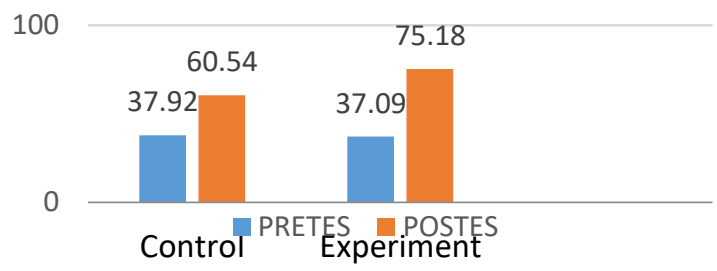

Figure 1. Value Diagram of Critical Thinking Ability in Control and Experiment Classes

The diagram above shows that the value of critical thinking skills of the control class and experiment after learning is applied by making a different Z-generation video. Test results with MANOVA show that this value has a probability of 0.00 . This means that if $p<0.05$, the two values differ significantly.

The difference is because in learning by making a Z-generation video students are faced with real-world conditions in exploring the material. Whereas if conventional learning students are only confronted with material in the form of writing, so that students are only required to memorize not to think in higher levels. This is consistent with Johnson's theory that To help students develop their intellectual processes, the CTL learning model in this study uses the generation of $\mathrm{Z}$ video production to teach steps that can be used in critical and creative thinking and provide opportunities to use thinking skills at different levels (Johnson, 2002).

The teaching and learning system by making Zgeneration video is a system of intellectual 
achievement that comes from active participation and experiencing meaningful experiences. Meaningful experiences that are commonly experienced by students in daily activities associated with the knowledge to be learned will make students more accustomed to critical thinking.

The making of this Z-generation video starts with creating a scenario outline for the drama or scene that will be performed on the video. These scenes are arranged according to the style of Z-generation children who currently like Korean films. Furthermore, making music arrangements and song lyrics for videos using songs that were famous in the era of Z-generation. The song is taken from famous music and song lyrics are adapted to the scenes and adapted to the frame system material. Videos made are then presented in MP4 format and presented in class and uploaded to you tube. The video that has been made is a source of learning.

The day-to-day experience contained in the Zgeneration skeletal video system will make students more realistic and responsive in explaining the joints, muscles, bone types, and benefits contained in the brand's everyday boredom. With the daily events they do, students will find information available from these events, which leads them to discover a concept of joints, bones, and muscles. They can do this if students have critical thinking skills. Critical thinking allows students to find the truth amid a flood of information that surrounds them every day.

Learning by making a Z-generation video in this experimental class uses 7 standard steps from the Contextual Teaching and Learning model in the learning process of each meeting, namely constructivism, questioning, modelling, learning community, inquiry, authentic assessment, and reflection. Learning by making a Z-generation video is done with the Contextual Teaching and Learning model.

The first syntax is constructivism and questioning. At the beginning of learning students construct their experiences with lessons that will be discussed and prepared to make a Z-generation video. For example in joint material and the mechanism of muscle movement, at this meeting learning is opened by asking about joints in the skeletal system, "When you walk, joints what are involved?" or questions like" Why can we write and lift chairs, are the parts of your body involved so that we can carry out such activities? "Questions like these that will provoke students to associate learning with their daily activities. They will relate their daily activities to the skeletal system material and they will present it in the Z-generation video. By linking the material and activities that students normally do, students will be encouraged and interested in thinking deeper. The application of learning by making constructivism-based Z-generation videos can make students see the material they will learn with the learning media in the form of their daily experiences. With these daily experiences students will be more responsive and active in understanding the material. Material that is closely related to students' daily lives makes students more interested in thinking critically.

The next principle is learning community. Students are required to explore what students have that are built through the learning community. So that in this case because learning in groups of students is required to express their ideas related to what they are to be presented in the Z-generation video. For example, with the scenes in the video presenting when they are running, then in the video students will connect with the material of the skeletal system that is what joints and muscles are involved. Students will be together in groups to discuss and answer the relationship between the movement scenes in the video with the material skeletal system. So with these activities students will be required to think critically and think more carefully in solving problems in practicum activities in the Zgeneration video.

Learning in groups as explained in the learning example above allows many ideas to come in to look for lyrics that fit the movement scene in the Zgeneration video. Group members must have critical thinking in accommodating ideas that must be used and reject ideas that are not appropriate. In their group discussions they must deliberate in working on reports or completing the task of making videos. Deliberation activities familiarize them with being able to think critically in taking ideas or thoughts which would be used to make reports or assignments. The activity of receiving and filtering an idea will greatly train students to be able to think critically.

The next principle is inquiry. Inquiry is a process of discovering a concept. In this principle, a worksheet is carried out which contains making a Zgeneration video by linking it to the skeletal system material. This causes students to think more deeply and construct the experiences students have in relation to the video that will be presented so that all skeletal systems are well coordinated. Students will conduct an in-depth study of what is done in a dance movement with what muscles play, what joints play, what bones play a role.

Inquiry is a process of discovering concepts. Students will be asked at this practicum to find concepts such as what the shape of the bone, short, is flat, like what the structure of hard and cartilage bones, as well as connecting the function of bones with their 
shape and structure. Critical thinking is always used in finding concepts derived from facts. For example, students want to connect bone shape and bone function. Strong and long bones are always associated with the function of supporting the body. They must use the ability to think critically to get the concept if the bone pipe functions to support the body and flat bones to protect organs. They will connect the facts of form and structure to get the concept of bone function. The process of linking between facts to be able to find concepts requires critical thinking skills.

The next CTL principle is authentic assessment. Authentic assessment is an assessment of what students do. In this study authentic assessment is done by taking scores at each meeting. The assessment is in the form of an assessment of the preliminary practicum report, the project report after making the project, an assessment of the presentation process, and the result sheet working on the worksheet. Authentic assessment that requires students to produce products in the form of reports of what students do at each meeting. Making a report will make students work together and exchange ideas and dare to express their opinions when making a report, students will unite various opinions and find the right concepts using critical thinking skills. Making a report will get a lot of input opinions and ideas, then students must be able to unite opinions and equate perceptions so that the report can be prepared properly. The process of sorting out ideas and equating opinions requires a critical thought.

This authentic assessment principle asks students to present the results of the project to other students in front of the class. For example, by making a skeletal system video and aids to the mechanism of muscle movement. Students who have made a project are asked to be able to explain to their friends what the project means and how the project works. Students are required to be able to explain in front of the class without reading and in their own words will be able to train students to be able to think critically about a condition. At the time of their presentation there were also questions that were spontaneously raised by their friends which had to be answered correctly by the students who were presenting. When answering questions directly and in a short time, students will use critical thinking skills. Therefore, with the authentic assessment process, students' critical thinking skills will be honed.

Critical thinking skills of students are improved in addition to being seen from quantitative data with SPSS tests can also be seen with qualitative data from researcher observations and student sheet work. Students experimental class who at the first meeting seemed lazy practicum and lazy discussion, after the 4th, 5th and 6th meetings became more active. This can be seen when students who work in group discussion activities become more active and all children speak, besides that it can be seen from the practicum reports from meetings 1 to 5 that the report results are more complete and detailed. Compared to students in the control class, students in the experimental class when the teacher asked questions or offered someone who wanted to ask the experimental class asked more questions and answered questions compared to the control class. Control class students tend to be quiet and unresponsive to teacher questions or offers. That's because students from the passive control class and there are rarely activities such as practicums, group discussions, presentations.

\section{CONCLUSION}

Learning that uses the learning with generation $\mathrm{Z}$ video is very effective for improving critical thinking ability. Students will better understand the material and be critical of daily activities related to the material of the motion system when applied to learning with the Contextual lteaching and learning approach that makes learning videos of $\mathrm{Z}$-generation.

\section{REFERENCES}

[1] Bell, S., 2010. Project-Based Learning for the 21st Century: Skills for the Future. Clear. House A J. Educ. Strateg. Issues Ideas. https://doi.org/10.1080/00098650903505415

[2] Buckley, J., Archibald, T., Hargraves, M., Trochim, W.M., 2015. Defining and Teaching Evaluative Thinking: Insights From Research on Critical Thinking. Am. J. Eval. https://doi.org/10.1177/1098214015581706

[3] Cogan-Drew, D., 2010. 21st Century Skills. eLearn. https://doi.org/10.1145/1719292.1730970

[4] Danver, S.L., 2016. Contextual Teaching and Learning, in: The SAGE Encyclopedia of Online Education. https://doi.org/10.4135/9781483318332.n86

[5] Hudson, C.C., Whisler, V.R., 2007. Contextual teaching and learning for practitioners, in: IMSCI 2007 - International Multi-Conference on Society, Cybernetics and Informatics, Proceedings.

[6] Johnson, E.B., 2002. Contextual Teaching and Learning: What It Is and Why It's Here to Stay. Corwin Press, New York.

[7] Johnson, P., 2009. The 21st century skills movement. Educ. Leadersh. 
[8] Joyce, B.R., Weil, M., Calhoun, E., 1996. Models of Teaching, 5th Edition, Models of teaching.

[9] Naibaho, L. (2019). The Integration of Group Discussion Method Using Audio Visual Learning Media toward Students' learning Achievement on Listening. International Journal of Research-Granthaalayah, 7(8), 438-445.

[10]Moon, J., 2007. Critical thinking: An exploration of theory and practice, Critical Thinking: An Exploration of Theory and Practice. https://doi.org/10.4324/9780203944882

[11] Nadeak, B., \& Naibaho, L. (2020). VideoBased Learning on Improving Students' learning Output.PalArch's Journal of Archaeology of Egypt/Egyptology, 17(2), 4454.

[12] Nadeak, B., \& Naibaho, L. (2019, November). Investigating the effect of learning multimedia and thinking style preference on learning achievement on anatomy at Universitas Kristen Indonesia. In Journal of Physics: Conference Series (Vol. 1387, No. 1, p. 012116). IOP Publishing.

[13] Sanders, M., Moulenbelt, J., 2011. Defining Critical Thinking. Inq. Crit. Think. Across Discip.

https://doi.org/10.5840/inquiryctnews201126 16

[14] Tyas, E. H., \& Naibaho, L. (2021). HOTS Learning Model Improves the Quality of Education. International Journal of ResearchGRANTHAALAYAH, 9(1), 176-182.

[15] van Laar, E., van Deursen, A.J.A.M., van Dijk, J.A.G.M., de Haan, J., 2017. The relation between 21st-century skills and digital skills: A systematic literature review. Comput. Human Behav. https://doi.org/10.1016/j.chb.2017.03.010. 